\title{
STUDI KUALITATIF TENTANG PELAYANAN KESEHATAN REPRODUKSI REMAJA: PERSPEKTIF REMAJA, IBU MUDA DAN PETUGAS PELAYANAN
}

\author{
Herlin Fitriana Kurniawati, "Andari Wuri Astuti \\ Kebidanan, Fakultas IImu Kesehatan, Universitas ‘Aisyiyah Yogyakarta, 'Email: astutiandari@unisayogya.ac.id
}

\begin{tabular}{l}
\hline \hline INFO ARTIKEL \\
\hline Riwayat Artikel: \\
Diterima: 1 1-10-2019 \\
Disetujui: 28-07-2020
\end{tabular}

Kata Kunci:

Kesehatan Reproduksi

Remaja

Kualitatif

PKPR

\section{ABSTRAK}

\begin{abstract}
Abstrak: Pemerintah Indonesia telah berupaya mengatasi masalah Kesehatan Reproduksi Remaja (KRR) salah satunya dengan Pelayanan Kesehatan Peduli Remaja (PKPR), namun data nasional menunjukkan remaja masih mempunyai tingkat kesadaran yang rendah terkait dengan pentingnya KRR. Gunungkidul, merupakan salah satu kabupaten yang mempunyai angka kehamilan remaja tinggi, tahun 2016 terjadi 310 kehamilan remaja dengan 220 diantaranya merupakan kehamilan sebelum menikah. Tujuan penelitian ini adalah untuk mengkaji pelayanan kesehatan reproduksi remaja di PKPR dari perspektif remaja, ibu muda dan pemberi pelayanan kesehatan. Penelitian ini adalah generic qualitative research dengan desain in-depth-study. Partisipan dalam penelitian ini adalah 10 remaja, 10 ibu muda dan 10 petugas pelayanan kesehatan. Pengambilan data dilakukan dengan one-to-one in depth interview, dengan waktu paling lama adalah 60 menit. Analisis data menggunakan thematik analisis dengan mengadopsi strategi Collaizi. PKPR telah menyediakan pelayanan KRR, namun pelayanan ini belum banyak diakses oleh remaja dikarenakan tekanan social yang membatasi akses pelayanan tersebut misalnya rasa enggan dan malu. Sumber yang sering diakses oleh remaja untuk mencari informasi terkait dengan KRR adalah internet dan teman sebayanya. Kehamilan remaja adalah akibat remaja melakukan hubungan seksual sebelum menikah dan sebelumnya mereka telah mempraktekkan tindakan mencegah kehamilan menggunakan metode kontrasepsi tradisional. Semua ibu muda juga menyatakan bahwa mereka telah melakukan upaya mengakhiri kehamilan dengan beberapa cara tradisional dan ilegal. Pelayanan KRR perlu didesain dengan prinsip youth friendly dan cultural sensitive sesuai konteks di Indonesia. Upaya meningkatkan KRR perlu melibatkan orang tua sehingga peningkatan kesadaran dan pengetahuan remaja bisa meningkat dimulai dari orang terdekat yaitu keluarga, yang selanjutnya secara potensial bisa menurukan angka kehamilan remaja.
\end{abstract}

\begin{abstract}
Adolescents Sexual and Reproductive Health (ASRH) is a global health concern. In order to address ASRH issues, Indonesian government initiated ASRH services, however, national data show that there is still low level of awareness related to ASRH and high number of adolescent pregnancy i.e. 48 per 1,000. Gunungkidul is one of municipality that has high number of adolescent pregnancy i.e. 303 adolescent pregnancy occurred in 2016 and 202 of them due to premarital sexual relationship. This study aimed to investigate ASRH service from the perspective of adolescents, young mother and health care providers. This study used generic qualitative research by using in-depth study. There were 10 adolescents, 10 young mothers and 10 healthcare providers participated within this study. Data were gathered by using one to one in depth interview, and the length of interview was length about 60 minutes. Data were analysed by using thematic analysis and Collaizi framework as a framework. Findings shows that although ASRH services have been provided within health facilities, there is low access of the services due to social constraint such as shame and reluctant. Adolescents preference of obtaining information related sexual and reproductive were internet and peers. Adolescent pregnancy was a consequence of premarital sexual relationship and adolescents were practicing traditional contraception methods to prevent pregnancy, as well as tried to terminating their pregnancy. There is a need of tailoring ASRH services which considered youth friendly and cultural sensitive within Indonesian context. Involving parents in the programme of campaigning and promoting SRH may be benefit to increase awareness of $A S R H$, and subsequently reduce adolescent pregnancy.
\end{abstract}

\section{A. LATAR BELAKANG}

Masa remaja adalah periode yang penting untuk diperhatikan dikarenakan pada masa ini terjadi peralihan dari usia anak-anak menjadi usia dewasa, dan pada masa ini terjadi perubahan baik dalam aspek kognitif, fisik, hormonal dan mental (WHO (World Health Organitation), 2015). Pada masa peralihan tersebut, jika remaja yang tidak mendapatkan support yang adekuat seringkali mereka terjerumus pada perilaku yang membahayakan, salah satunya perilaku seksual dan reproduksi yang berbahaya (Mbeba et al., 2012). Kesehatan reproduksi remaja adalah suatu keadaan sehat jasmani, psikologis, dan sosial yang berhubungan dengan fungsi dan proses sistem 
reproduksi pada remaja (WHO, 2017). Pengertian sehat tersebut tidak semata-mata berarti terbebas dari penyakit atau kecacatan namun juga sehat secara mental serta sosial-kultural. Survei Demografi Kesehatan Indonesia melaporkan bahwa, adanya kesenjangan dalam pembinaan pemahaman remaja tentang Kesehatan Reproduksi Remaja (KRR) yang tergambar pada tingkat kelahiran remaja kelompok usia 15-19 tahun yang disebabkan oleh tingkat pengetahuan remaja mengenai kesehatan reproduksi remaja masih rendah dan cakupan peran Pelayanan Kesehatan Peduli Remaja (PKPR) belum optimal (Kemenkes, 2017).

Penelitian terdahulu menunjukkan bahwa kehamilan remaja mempunyai faktor resiko lebih tinggi mengalami outcome negatif pada aspek fisik dan psikososial baik pada ibu, bayi maupun suaminya (McHunu, G., Peltzer, K., Tutshana, B. and Seutlwadi, 2012). Pada aspek fisik, kehamilan remaja mempunyai beresiko terhadap kejadian komplikasi kehamilan dan persalinan, contohnya kejadian anemia pada kehamilan, persalinan macet, keguguran, cepalo pelvic disporoportion, persalinan pre term, intra uterine fetal death, intra uterine growth retardation, berat badan lahir rendah,dan stunting pada anak (Morris and Rushwan, 2015). Selain itu, kehamilan remaja juga menunjukkan dampak negatif psikososial misalnya ketidaksiapan menjadi orang tua baik secara mental maupun finansial, ekslusi sosial, drop out sekolah, stigma negatif pada ibu, bayi dan keluarga (Anjarwati et al., 2019). Menurut WHO (2014), tingginya angka kehamilan remaja di negara berkembang disebabkan berbagai macam faktor misalnya kurangnya pengetahuan tentang kesehatan reproduksi remaja serta sikap yang kurang peduli kesehatan reproduksinya, tidak tersedianya akses mengenai informasi dan pelayanan kesehatan reproduksi remaja termasuk kontrasepsi, budaya lokal misalnya pernikahan anak, tekanan peer untuk melakukan hubungan sexual, maraknya pornografi, pemerkosaan, pola asuh dalam keluarga yang salah dan tidak tersedianya fasilitas kesehatan yang khusus memberikan pelayanan kesehatan reproduksi remaja.

Kabupaten Gunungkidul, merupakan salah satu kabupaten di Yogyakarta yang mempunyai angka kehamilan remaja yang tinggi. Pada tahun 2016 terjadi 310 kehamilan remaja dengan 220 diantaranya merupakan kehamilan pra nikah (Dinas Kesehatan Kabupaten Gunungkidul, 2017). Melihat fenomena tersebut, penelitian ini bertujuan untuk untuk mengkaji pelayanan kesehatan reproduksi remaja di PKPR dari perspektif remaja, ibu muda dan pemberi pelayanan kesehatan, untuk memperoleh gambaran terkini terkait dengan pelayanan kesehatan reproduksi pada PKPR di Gunungkidul dan mengetahui aspek yang menjadi hambatan pelayanan kesehatan reproduksi remaja sehingga angka kehamilan remaja di Gunungkidul masih tinggi.

\section{B. METODE PENELITIAN}

Penelitian ini adalah penelitian generic qualitative exploratory yang meneliti pengalaman tentang pelayanan kesehatan reproduksi di PKPR dari perspektif remaja, ibu muda dan penyedia pelayanan kesehatan. Penelitian generic exploratory qualitative sangat tepat untuk digunakan ketika peneliti ingin menggali dan memahami secara mendalam tentang pengalaman individu maupun kelompok terkait sebuah topic (Flick, U., Flick, U., Kvale, S., Angrosino, M.V., Barbour, R.S., Banks, M., Gibbs, G., Rapley, T. and Flick, 2007). Penelitian generic qualitative exploratory juga sangat baik untuk digunakan untuk menggambarkan secara narratif pengalaman individu ataupun kelompok dalam sebuah laporan penelitian secara detail dan mendalam (Morse, 2001).

Pengambilan sampel penelitian dalam penelitian ini dengan menggunakan teknik non probability technique sampling dengan pendekatan purposive sampling dan kriteria inklusi dan eksklusi ditetapkan untuk memilih partisipan. Teknik pengambilan sampel dengan purposive sampling merupakan teknik yang dinilai tepat untuk dilakukan dalam penelitian yang menggali topik sensitif misalnya paparan cocaine pada ibu hamil, pengambilan keputusan untuk aborsi pada kehamilan tidak diinginkan, kehamilan remaja dan pengalaman ibu hamil dengan HIV (Creswell, J.W. and Creswell, 2013). Partisipan terdiri dari 10 remaja, 10 ibu muda 9yang mempunyai riwayat kehamilan sebelum menikah) dan 10 petugas pelayanan kesehatan.

Data dikumpulkan melalui one-to-one in depth interview selama kurang lebih 60 menit. Interview dilakukan mulai bulan Mei sampai dengan Agustus 2019. Lokasi penelitian adalah 3 puskesmas di wilayah Gunungkidul dan penelitian di lakukan setelah mendapatkan ethical approval dari Komisi Etik Penelitian Unievrsitas Respati Yogyakarta dengan No (143.3/FIKES/PL/V/2019). Analisis data menggunakan strategi yang diadopsi dari framework Collaizi (1978) dan N Vivo versi 10 digunakan sebagai data management untuk membantu proses analisis.

\section{HASIL DAN PEMBAHASAN}

Tiga tema besar muncul dalam penelitian kualitatif yaitu ketersediaan pelayanan kesehatan, informasi kesehatan reproduksi remaja, harapan terkait kesehatan reproduksi remaja. Diagram 1 menggambarkan hasil tema yang muncul dari penelitian kualitatif ini: 


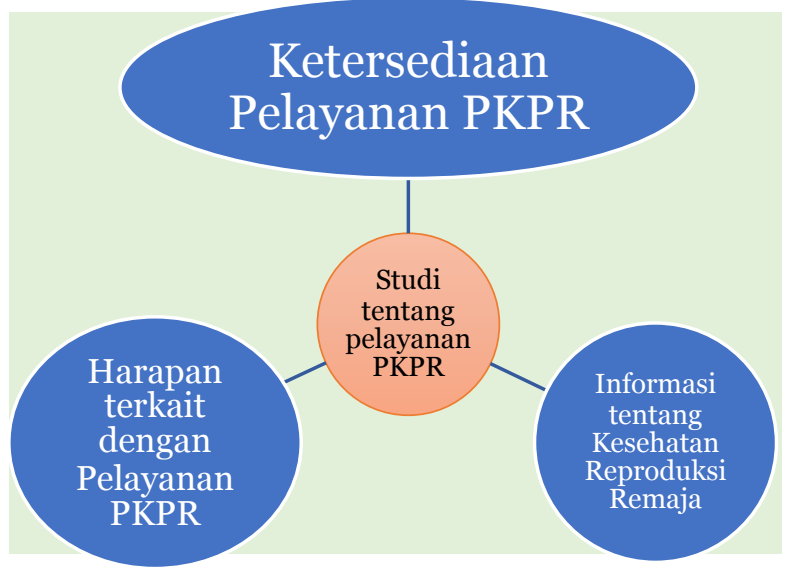

Diagram 1: Tema penelitian

\section{Ketersediaan Pelayanan PKPR}

Tema "Ketersediaan pelayanan PKPR" mendeskripsikan persepsi dari partisipan terkait dengan penyediaan pelayanan PKPR meliputi ketersediaan akses, ketersediaan sumber daya dan sumber dana. Partisipan remaja menyampaikan bahwa mereka mengetahui pelayanan kesehatan remaja, tetapi mereka enggan mengakses pelayanan tersebut disebabkan kekhawatiran akan terjadi tekanan sosial dari keluarga, teman maupun masyarakat. Kondisi tersebut dijelaskan oleh Partisipan 2 sebagai berikut:

"...saya tahu ada itu pelayanan kesehatan reproduksi untuk kami-kami yang usianya remaja (pause) tapi kan malu yaaa datang kesana (pause) lha mosok anak bawang kayak saya nanti tanya-tanya tentang masalah orang dewasa (seksualitas dan reproduksi).....nanti apa kata orang (Partisipan 2, remaja, 16 tahun)

Pengalaman serupa juga di disampaikan oleh ibu muda sebagai berikut:

....nah dulu memang ada itu disampaikan sama bu guru $B K$, kalau nggak salah juga kita ada itu pos nya itu di deket UKS tapi ya sepi tuu....nggak ada yang datang-datang juga, dulu pingin sih berkunjung tapi malu juga mbak....nanti dikira saya punya masalah (tertawa)...padahal iya juga sih.....(Partisipan 18, ibu muda 18 tahun)

Hal ini dikonfirmasi oleh petugas pelayanan kesehatan sebagai berikut: .....kita sebenernya sudah jalan itu mbak (pause) kita juga turun ke sekolah-sekolah dan desa-desa (pause) tapi ya itu semakin kesini memang semakin tidak banyak kegiatan dan kita melihat memang anak-anak itu hanya datang kalau ada masalah (pause) itupun hanya satu atau dua anak yang terbuka....kemungkinan mereka malu atau mungkin terpengaruh budaya sekitar kalau udah denger kata-kata reprodusi itu mengarahnya ke hal-hal yang tidak baik...(Partisipan 25, bidan koordinator PKPR)

Hasil penelitian juga menunjukkan bahwa selain tekanan sosial yang membatasi remaja mengakses pelayanan PKPR, beberapa alasan menjadi penghambat remaja tidak mengakses pelayanan PKPR, misalnya tidak percaya dengan petugas ataupun peer konselor, ketidakhadiran petugas, dan kurang menariknya media yang digunakan untuk media promosi. Remaja menyampaikan pandangannya:

......aku tau juga sih itu ada temen-temen yang dilatih kan (pause) jadi kalau kita mau konsul gitu sama mereka (pause) eh tapi kan itu bahaya kan? Nanti bisa aja mereka nyebar-nyebarin curhat kita...apalagi kalau nanti mereka lagi sebel sama kita kan? Jadi mending aku pendem atau liat internet paling banter (partisipan 4, remaja, umur 17 tahun)

Selain itu, sebagian ibu muda juga menyampaikan jika mereka kurang mempercayai petugas PKPR, seperti yang disampaikan oleh ibu muda berikut:

....ibu-ibu tu kita baru aja lewat udah matanya melihat gimana gitu lho (pause) kayak nggak suka (pause) judes.....mau curhat kan ya mikir-mikir jadinya...takut $e$ nati disalah-salahke ngono lho mbak...judeg kan dadine mau curhat kesiapa (Partisipan 13, ibu muda, umur 17 tahun) 
Kondisi tersebut juga disampaikan oleh petugas pelayanan kesehatan:

.....kita sadar juga sih kan tidak semua bidan disini bisa deket dan bersahabat dengan remaja (pause) kadang mereka memang belum terpapar pelatihan kespro remaja (pause) kan kita dijatah juga harus satu puskesmas maksimal satu orang....dana juga jadi masalah lho (pause) program ya gak bisa jalan kalau kita nggak ada dana...diminta program menarik tapi kalau nggak ada dana ya sama saja zonk.....(Partisipan 30, bidan koordinator)

Selain itu, ketersediaan sarana dan prasarana juga menjadi hambatan tersendiri ketersediaan pelayanan PKPR:

"kami sudah mempunyai program tersebut (PKPR), namun demikian ruangnya masih bergantian dengan ruang MTBS (Manajemen Terpadu Balita Sakit)......harus bergantigantian karena jujur saja PKPR ini sepi pengunjung....kami juga melakukan kunjungan ke sekolah-sekolah tapi hal ini juga tidak bisa rutin karena kurangnya tenaga dan waktu.... (Partisipan 29, bidan)

Kebijakan terkait dengan pelayanan PKPR juga menjadi aspek yang menjadi alasan ketidakoptimalan pelayanan PKPR, seperti yang disampaikan oleh bidan sebagai berikut:

"memang PKPR ini ada dan tiada kalau saya bilang (pause) mungkin karena bukan program prioritas puskesmas, sehingga dana nya pun kurang untuk kami membuat program-program, ditambah lagi tenaganya sangat terbatas (pause) apalagi yang sudah dilatih hanya saya saja...(Partisipan 24, bidan koordinator PKPR)

\section{Informasi tentang Kesehatan Reproduksi Remaja (KRR)}

Tema "Informasi tentang Kesehatan Reproduksi Remaja (KRR)” mendeskripsikan pengalaman partisipan terkait dengan sumber, media dan akses informasi terkait dengan KRR. Mayoritas remaja dan ibu muda menyampaikan bahwa materi dan cara penyampaian yang tidak "friendly" tentang kesehatan reproduksi remaja juga menjadi alasan remaja menjadi tidak tertarik, seperti kutipan berikut:

.....ibu-ibunya ngasih materi biasanya kan di hall itu banyak banget orang-orang nya jadi nggak fokus (pause) sama seringnya bikin ngantuk soale uyel-uyelan sama template juga panas (pause) jadinya kita malah ngobrol

dibelakang....(partisipan 10 , remaja, 16 tahun)

Selain itu strategi promosi juga menjadi alasan remaja tidak bisa mengakses pelayanan PKPR seperti yang disampaikan oleh ibu muda sebagai berikut

\section{....acarane kalau ndak salah itu sebulan sekali atau 2 bulan sekali terus kita kan ndak semuanya (pause) sekelas cuma 5 anak jadi kan ndak semua dapet (pause) bisa jadi pas kita dapet pas narasumbernya nggak asik...pengalaman pribadi sih itu mbak....(partisipan 17, ibu muda 18 tahun).}

Petugas pelayanan juga menyampaikan jika mereka mempunyai keterbatasan waktu dan media dalam menyampaikan informasi KRR kepada remaja, seperti yang disampaikan oleh bidan sebagai berikut:

...medianya lho dikit banget
(pause) diminta pakai
youtube nah ini kalau di
gunung ini kan ya ndakjalan
(pause) udah gitu mbak ini
tenaganya kurang cukup
kalau harus ekstra datang ke
sekolah-sekolah tiap minggu
(pause) kethetheran lah
pokoknya.... (Partisipan 21,
bidan)

Selain itu, sumber informasi yang paling popular diakses oleh sebagian besar remaja adalah media digital, internet dan teman sebaya. 
Partisipan 9 mengartikulasikan pengalamannya dalam kuote berikut:

.....kalau aku mau tahu
tentang mens, tentang
pubertas gitu paling aku
tanya temen (pause) atau
kalau ndak yak an ada
internet tuh (pause) kan jadi
rahasia....(Partisipan
remaja, 16 tahun)

Remaja juga mengakses beberapa situs pornography karena penasaran tentang seksualitas, seperti yang disampaikan oleh ibu muda menceritakan pengalamannya sebelum kehamilannya terjadi:

...pernah itu kita pada saat
pacaran kan (pause) dia
(pacar) ngajakin nonton BF
(blue film) di youtube...saya
penasaran aja gimana sih
isinya (pause).....habis itu
kayak kalau ketemuan
nonton itu....habis itu dia
ngajakin gituan (hubungan
seksual)...(Partisipan 18, ibu
muda, 17tahun)

Selain itu beberapa praktik reproduksi berbahaya juga dilakukan karena mendapatkan informasi dari internet. Ibu muda menyampaikan pengalamannya:

....saya waktu tahu hamil terus

pijat-pijat perut, minum jamu gitu.......taunya dari internet mbak sama ada itu layanan anti hamil gitu.....(Partisipan 12, ibu muda, 16 tahun)

Kondisi tersebut juga disampaikan oleh semua pemberi pelayanan kesehatan, seperti yang disampaikan oleh bidan sebagai berikut:

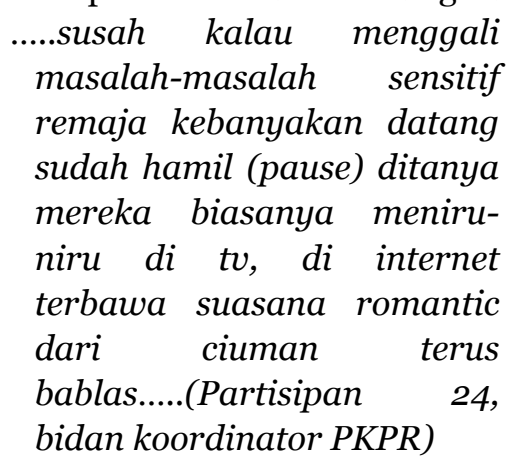

Media internet juga menjadi bahan rujukan sebagian besar ibu muda untuk mempraktekkan metode kontrasepsi tradisional, ibu muda berikut menceritakan pengalamannya:

$$
\begin{gathered}
\text {..dulu suka pakai layanan } \\
\text { online chat di internet } \\
\text { kan..... terus kan ngaku }
\end{gathered}
$$

sudah menikah kan (pause) terus konsultasi kb kalender gitu....terus sekitar 1 tahunan kita aman habis itu hamil....(Partisipan 19, ibu muda, 18 tahun)

\section{Harapan terkait dengan Pelayanan PKPR}

Tema "Harapan terkait dengan Pelayanan PKPR" menjelaskan tentang pendapat partisipan terkait upaya yang harusnya dilakukan untuk meingkatkan pelayanan PKPR dan pelayanan ideal yang bisa memenuhi kebutuhan remaja. Sebagian besar remaja menyebutkan bahwa mereka mengharapkan pelayanan yang ramah dan bersahabat. Kutipan dari partisipan berikut merepresentasikan sebagian besar harapan partisipan remaja dan ibu muda:

\section{.... harusnya kan mereka lebih gaul sama remaja (pause) jangan pasang muka jutek dulu nanti pada kabur (pause) terus pake medianya yang gambar-gambar banyak gitu biar bagus..(Partisipan 1, remaja, 16 tahun) \\ "... saya pernah dua kali datang ke Puskesmas waktu pertama tahu hamil ada bidan yang baik banget sampai kasih nasehat tentang kehamilan saya ini (pause) saya waktu itu padahal lagi stress banget tapi bidannya kayak ngertiin banget) (Ibu muda 8, umur 18 tahun, pasca melahirkan, keluar dari pekerjaan karena hamil diluar nikah)}

Remaja juga menginginkan pelayanan kesehatan reproduksi yang khusus disediakan untuk kelompok ibu muda, yang disampaikan oleh ibu muda:

....harusnya jangan dicampur sama ibu-ibu yang lain gitu (pause) soalnya kan seringnya mereka lihat aku terus ngeliatnya gimana gitu (pause) bikin keki....mungkin dalam pikirannya kecil amat kok udah hamil.....(partisipan 11, ibu muda, 17 tahun) 
Petugas pelayanan kesehatan juga menyampaikan bahwa pelayanan PKPR perlu memerlukan beberapa strategi supaya bisa menjadi rujukan adekuat bagi remaja untuk memperoleh informasi KRR. Partisipan 21 menyampaikan pendapatnya:

.....seharusnya ada training
khusus, budget khusus,
tambahan pegawai dan juga
mungkin perlu training
dengan teman sejawat selain
bidan kayak misal psikolog
(pause) kalau kita sudah
terlatih sudah terampil kan
kita bisa bikin program yang
inovatif....(Partisipan 21,
bidan)

Sebagian besar bidan juga menyebutkan bahwa keberpihakan dari kebijakan merupakan aspek penting supaya program KRR berjalan optimal.

....dulu waktu kita lagi
gencar-gencarnya promosi
kespro remaja (pause)
semuanya jalan bahkan kita
sampai turun itu ke dusun
korodinasi sama kader
(pause) tapi sekarang lagi
yang digencar-gencarkan
stunting kan...jadi ya
sekarang semua tenaga
diarahkan kesana....oleh
karenanya kita sih berharap
ya program KRR di support
seperti yang lalu
lalu.(Partisipan 27, bidan)

\section{TEMUAN ATAU DISKUSI}

Penelitian kualitatif ini bertujuan untuk mengkaji mengkaji pelayanan kesehatan reproduksi remaja di PKPR dari perspektif remaja, ibu muda dan pemberi pelayanan kesehatan. Hasil penelitian menunjukkan bahwa pelayanan PKPR telah menyediakan pelayanan kesehatan reproduksi remaja namun beberapa aspek menjadi penghambat remaja untuk mengakses pelayanan kesehatan yaitu tekanan sosial, perasaan enggan dan malu. Hal ini sesuai dengan penelitian yang telah dilakukan dibeberapa negara berkembang yang menyebutkan bahwa topik terkait dengan seksualitas dan reproduksi seringkali menjadi hambatan tenaga kesehatan untuk melakukan kampanye dan promosi kesehatan reproduksi (Folayan et al., 2014; Sivagurunathan et al., 2015; Mbugua and Karonjo, 2018). Seksualitas dan reproduksi merupakan issue yang sensitive dan pada beberapa masyarakat dianggap tabu, oleh karenanya beberapa penelitian merekomendasikan untuk mendesain program intervensi KRR yang ramah dengan konteks lokal (Acharya et al., 2010; Titiloye and Ajuwon, 2017). Selain itu, kurangnya kepercayaan terhadap penyedia pelayanan kesehatan mengakibatkan remaja memutuskan untuk tidak mengakses pelayanan kesehatan. Penelitian lain menyebutkan hal serupa namun didalam konteks berbeda menyebutkan bahwa rasa percaya kepada tenaga kesehatan menjadi aspek kunci pelayanan kesehatan berjalan optimal, karena ketika pasien percaya dengan petugas pelayanan kesehatan mereka akan lebih kooperatif dan fleksibel dalam menerima nasehat dan treatment dari tenaga kesehatan (Gaab et al., 2017).

Hasil penelitian ini juga menunjukkan bahwa hambatan yang dialami oleh penyedia layanan adalah kurangnya fasilitas untuk menyediakan layanan kesehatan reproduksi, misalnya keterbatasan infrastruktur dan media, serta minimnya support kebijakan yang mendukung program intervensi KRR. Sarana dan prasarana yang mendukung pelayanan kesehatan reproduksi perlu disiapkan dan disediakan secara detail dan "youth friendly" misalnya menyediakan pelayanan KRR yang mudah diakses oleh remaja di kelompok-kelompok remaja dan sekolah-sekolah (Mahdikhani, Oveisi and Olfati, 2018). Membangun suasana pelayanan kesehatan yang "youth friendly" juga bisa menjadi strategi menarik remaja untuk berkunjung ke pusat pelayanan, dan mengikutsertakan teman sebaya juga merupakan strategi untuk menciptakan pelayanan kesehatan reproduksi yang youth friendly (Kiswati, 2011). Penelitian lain juga menyebutkan bahwa hal yang sangat penting dari promosi KRR adalah media yang digunakan harus tepat, misalnya pada era milenial ini remaja lebih menyukai segala sesuatu yang serba digital (Salam et al., 2016). Pembiayaan dalam program KRR juga menjadi salah satu hambatan yang dikemukanan oleh penyedia pelayanan dalam penelitian ini. Sebagian besar penyedia pelayanan kesehatan menyatakan bahwa support pembiayaan merupakan kunci program KRR berjalan (Salam et al., 2016; Fenwick, J., Toohill, J., Slavin, V., Creedy, D. K., \& Gamble, 2018).

Dalam kehidupan manusia internet memberikan pengaruh yang besar termasuk pada remaja dan membawa dampak positif maupun negatif. Penelitian ini juga menemukan jika sebagian remaja menggunakan internet untuk mencari infromasi terkait dengan KRR misalnya menstruasi, pubertas dan siklus hidup manusia, disisi lain beberapa remaja juga mengakses pornografi untuk mencari informasi tentang seksualitas. Oleh sebab itu, pada program intervensi untuk KRR perlu ditekankan kepada remaja bahwa tidak semua informasi yang diperoleh dari internet adalah benar (Widyastari, Shaluhiyah and 
Widjanarko, 2008), bahkan beberapa praktik-praktik berbahaya terkait dengan seksualitas dan reproduksi bersumber dari internet misalnya remaja melakukan hubungan seksualitas sebelum menikah karena terpengaruh media pornografi yang berdampak pada kehamilan remaja (Soltani et al., 2017). Sehingga, remaja perlu disarankan untuk bisa mengakses sumbersumber informasi KRR yang adekuat misalnya petugas tenaga kesehatan (Nguyen et al., 2019). Untuk merespon hal tersebut, pemberi pelayanan KRR juga perlu menjawab kebutuhan remaja dengan menciptakan inovasi misalnya menggunakan aplikasi berbasis mobile phone ataupun blog yang informative dan ramah remaja (Steinberg et al., 2018).

Skill dan ketrampilan pemberi pelayanaan yang kurang juga menjadi sorotan partisipan dalam penelitian ini, sehingga menyebabkan pelayanan KRR tidak bisa memenuhi kebutuhan remaja. Hal ini selaras dengan penelitian sebelumnya bahwa dalam memberikan pelayanan kepada remaja, pemberi pelayanan perlu dibekali pelatihan spesifik misalnya komunikasi efektif dengan remaja, ketrampilan konseling untuk remaja, bahasa dan media untuk mendekati dan menarik remaja, serta intervensi yang efektif pada program intervensi remaja (Nemade, Anjenaya and Gujar, 2009; Zulu et al., 2018). Namun demikian, menurut penelitian lain merekomendasikan bahwa skill dan kerampilan petugas pelayanan kesehatan yang cakap tidak cukup memberikan efektifitas yang tinggi dalam program KRR jika tidak ada upaya untuk mengikutsertakan orang tua dan tokoh masyarakat dalam program kampanye KRR di Indonesia (Miswanto, 2014).

Hasil penelitian ini juga menunjukkan bahwa kebutuhan terhadap pelayanan kesehatan reproduksi yang spesifik untuk remaja yang telah menikah (ibu muda dan pasangannya) juga perlu digarisbawahi, karena di Indonesia belum terdapat pelayanan kesehatan reproduksi yang antara ibu muda dan ibu dewasa. Sedangkan, ibu muda mempunyai resiko mengalami komplikasi kesehatan yang lebih tinggi dibandingkan dengan ibu dewasa. Penelitian menunjukkan bahwa ibu muda rentan untuk mengalami kelelahan, anemia, perdarahan, keguguran dan persalinan macet (Tamer Edirne et al., 2010). Selain itu bayi yang lahir dari ibu muda mempunyai resiko Intra Uterine Fetal Death (IUFD), Intra Uterine Growth Retardation (IUGR). Untuk itu dalam intervensi program KRR, sebaiknya petugas pelayanan kesehatan juga memberikan edukasi terkait dengan resiko kesehatan yang bisa dialami oleh remaja yang mengalami kehamilan (Anjarwati et al., 2019). Bahaya yang bisa dialami lainnya jika remaja hamil apalagi dikarenanan hubungan seksual sebelum menikah adalah stress, depresi, putus sekolah, dianggap pelanggar norma dan kesulitan ekonomi (Lazarus, K. and Rossouw, 2015).

\section{E. SIMPULAN DAN SARAN}

Pelayanan KRR telah tersedia di Puskesmas dan sekolah-sekolah namun beberapa aspek menjadi penghambat untuk optimalisasi pelayanan kesehatan misalnya sosial budaya, ketidaksiapan infrastruktur dan keterbatasan sumber daya manusia serta pendanaaan. Perlu dilakukan upaya untuk mendesain program intervensi yang sensitive terhadap budaya di Indonesia dan youth friendly. Dukungan advocacy dari pemangku kepentingan diperlukan untuk pelaksanaan program KRR, selain itu penelitian-penelitian terkait dengan model intervensi yang sesuai untuk dikembangkan di Indonesia perlu diinisiasi berdasarkan evidence terkini.

\section{UCAPAN TERIMA KASIH}

Tim penulis mengucapkan terima kasih kepada Kementrian Riset, Teknologi dan Pendidikan Tinggi Republik Indonesia yang telah memberikan dana penelitian melalui skema Penelitian Dosen Pemula. Penulis juga mengucapkan terimakasih kepada segenap partisipan yang terlibat dalam penelitian ini.

\section{DAFTAR RUJUKAN}

[1] Acharya, D. R. et al. (2010) 'Factors associated with teenage pregnancy in South Asia: a systematic review', health Science Jo, 4(1), pp. 3-14. doi: 10.1186/s12889015-1697-2.

[2] Anjarwati, A. et al. (2019) 'Studi tentang Pola Asuh, Pusat Informasi dan Konseling Kesehatan Reproduksi Remaja (PIK-KRR) dan Kejadian Kehamilan Remaja', Jurnal Ilmiah Bidan, 1(1). Available at: https://www.ejournal.ibi.or.id/index.php/jib/article/view/133/71.

[3] Creswell, J.W. and Creswell, J. . (2013) Qualitative inquiry \& research design: choosing among five approaches. 3rd edn. Los Angeles, Calif.; London: SAGE Publications.

[4] Dinas Kesehatan Kabupaten Gunungkidul (2017) Jumlah Kehamilan Remaja. Dinas Kesehatan Gunungkidul

[5] Fenwick, J., Toohill, J., Slavin, V., Creedy, D. K., \& Gamble, J. (2018) 'Improving psychoeducation for women fearful of childbirth: Evaluation of a research translation project', Women and Birth, 31(1), pp. 1-9.

[6] Flick, U., Flick, U., Kvale, S., Angrosino, M.V., Barbour, R.S., Banks, M., Gibbs, G., Rapley, T. and Flick, U. (2007) The Sage qualitative research kit. London: SAGE Publications.

[7] Folayan, M. O. et al. (2014) 'Differences in sexual behaviour and sexual practices of adolescents in Nigeria based on sex and self-reported HIV status', Reproductive Health, 11(1). doi: 10.1186/1742-4755-11-83.

[8] Gaab, J. et al. (2017) 'Trust in the health care professional and health outcome : A meta-analysis', PLoS Medicine, pp. 1-13. doi: 10.1371/journal.pone.0170988.

[9] Kemenkes (2017) Survei Demografi dan Kesehatan 2017.Kementrian Kesehatan Indonesia

[10] Kiswati (2011) 'Evaluasi Pelaksanaan Manajemen Program (PIK-KRR) Pusat Informasi dan Konseling Kesehatan Reproduksi Remaja Oleh Penyuluh Keluarga Berencana di Kabupaten Jember', pp. 36-45.

[11] Lazarus, K. and Rossouw, P. . (2015) 'Mother's 
expectations of parenthood: the impact of prenatal expectations on self-esteem, depression, anxiety, and stress post birth', Int $J$ Neuropsychotherapy, 3.

[12] Mahdikhani, Z., Oveisi, S. and Olfati, F. (2018) 'Clarifying the criteria for reproductive health counselling for adolescent girls by service providers : A qualitative study .', 29(11), pp. 2257-2264.

[13] Mbeba, R. M. et al. (2012) 'Barriers to sexual reproductive health services and rights among young people in Mtwara district , Tanzania : a qualitative study', 13(Supp 1), pp. 16.

[14] Mbugua, S. M. and Karonjo, J. M. (2018) 'Reproductive health knowledge among college students in Kenya'. BMC Public Health, pp. 1-7.

[15] McHunu, G., Peltzer, K., Tutshana, B. and Seutlwadi, L. (2012) 'Adolescent pregnancy and associated factors in South African youth', Afr Health Sci, 12(4)(4), pp. 426434.

[16] Miswanto (2014) 'Pentingnya Pendidikan Kesehatan Reproduksi dan Seksualitas pada Remaja', 3(2), pp. 111122.

[17] Morris, J. L. and Rushwan, H. (2015) 'International Journal of Gynecology and Obstetrics Adolescent sexual and reproductive health: The global challenges', International Journal of Gynecology and Obstetrics. Elsevier B.V., 131, pp. S40-S42. doi: 10.1016/j.ijgo.2015.02.006

[18] Morse, J. (2001) The nature of qualitative evidence. London: Sage Publications.

[19] Nemade, D., Anjenaya, S. and Gujar, R. (2009) 'Impact of health education on knowledge and practices about menstruation among adolescent school girls of Kalamboli, Navi-mumbai', Health and Population: Perspectives and Issues, 32(4), pp. 167-175.

[20]Nguyen, G. et al. (2019) 'Scaling-up Normative Change Interventions for Adolescent and Youth Reproductive Health: An Examination of the Evidence', Journal of Adolescent Health. Elsevier Inc., 64(4), pp. S16-S30. doi: 10.1016/j.jadohealth.2019.01.004.

[21] Salam, R. A. et al. (2016) 'Improving Adolescent Sexual and Reproductive Health: A Systematic Review of Potential Interventions', $59 . \quad$ doi: 10.1016/j.jadohealth.2016.05.022.

[22] Sivagurunathan, C. et al. (2015) 'Adolescent Health: Present Status and Its Related Programmes in India . Are We in the Right Direction?', 9(3). doi: 10.7860/JCDR/2015/11199.5649.

[23] Soltani, F. et al. (2017) 'Sources of Adolescents' Information about Sexual and Reproductive Health: Gender Similarities and Differences', 9(9), pp. 1624-1628.

[24] Steinberg, A. et al. (2018) 'Evaluation of a Mobile Phone App for Providing Adolescents With Sexual and Reproductive Health Information , New York City , 20132016', 133(3), pp. 234-239. doi: 10.1177/0033354918769289.

[25] Tamer Edirne et al. (2010) 'Trends, characteristics, and outcomes of adolescent pregnancy in eastern Turkey', International Journal of Gynecology \& Obstetrics, 110(2).

[26] Titiloye, M. A. and Ajuwon, A. J. (2017) 'Knowledge and quality of adolescents reproductive health communication between parents and their adolescents children in Ibadan , Nigeria', 8. doi: 10.4081/jphia.2017.

[27] WHO (2017) Adolescent Health. Available at: file://C:/Users/USER-PC/Downloads/WHO-MCA-17.09eng (2).pdf.

[28] WHO (World Health Organisation) (2015) World Health Organization, Maternal, newborn, child and adolescent health: adolescent pregnancy. Available at: http://www.who.int/maternal_child_adolescent/topics/ maternal/adolescent_pregnancy/en/.

[29] Widyastari, D. A., Shaluhiyah, Z. and Widjanarko, B. (2008) 'Adolescents In Peril : Internet And Other Factors Influencing Adolescents Â€ $€^{T m}$ Sexual Attitudes Remaja
Dalam Bahaya : Pengaruh Paparan Internet Dan Faktor Lain Terhadap Sikap Seksual Remaja Tahun 20o8'.

[30]Zulu, J. M. et al. (2018) 'Community based interventions for strengthening adolescent sexual reproductive health and rights : how can they be integrated and sustained? A realist evaluation protocol from Zambia'. Reproductive Health, pp. 1-8.

\section{PROFIL PENULIS KORESPONDENSI}

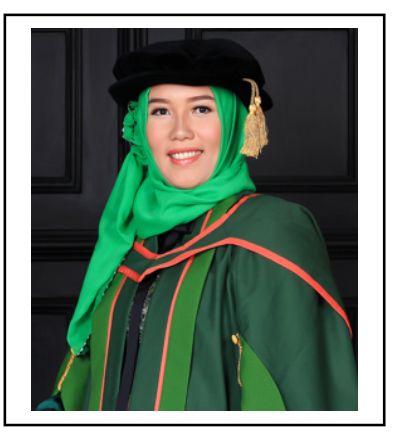

Nama : Andari Wuri Astuti., S.SiT., MPH., Ph.D

Tempat dan Tanggal lahir: Gunungkidul, 13 Mei 1985.

Riwayat Pendidikan:

D III Kebidanan, STIKES Aisyiyah Yogyakarta 2003-2006; D IV Kebidanan STIKES Ngudi Waluyo Ungaran (2007-2008); Master of Public Health, University of Leeds, United Kingdom (2011-2012); Ph.D in Midwifery, Maternal and Children Health, University of Leeds, United Kingdom (2013-2017). 